\title{
Seismic triggering of landslides, Part A: Field evidence from the Northern Tien Shan
}

\author{
H.-B. Havenith ${ }^{1}$, A. Strom ${ }^{2}$, D. Jongmans ${ }^{1,3}$, K. Abdrakhmatov ${ }^{4}$, D. Delvaux ${ }^{5}$, and P. Tréfois ${ }^{5}$ \\ ${ }^{1}$ GeomaC-LGIH, University of Liege, B52, 4000 Sart Tilman, Liege, Belgium \\ ${ }^{2}$ Hydroproject Institute, Volokolamskoje Shosse 2, 125933 Moscow, Russia \\ ${ }^{3}$ LIRIGM, Université Joseph Fourier Grenoble, BP53, 38041 Grenoble cedex 9, France \\ ${ }^{4}$ Kyrgyz Institute of Seismology, Mkr. Asanbai 52/1, 720060 Bishkek-60, Kyrgyzstan \\ ${ }^{5}$ Africamuseum, Department of Geology - Remote Sensing, Stw. Op Leuven 13, 3080 Tervuren, Belgium
}

Received: 12 August 2002 - Accepted: 24 October 2002

\begin{abstract}
Landslides triggered by strong earthquakes often caused most of the global damage and most of all casualties related to the events, such as shown by the $M=7.7$ Peru earthquake in 1970, by the $M=7.6 \mathrm{El}$ Salvador earthquake in 2001 or by the $M=7.4$ Khait (Tajikistan) earthquake in 1949. The obvious impact of a landslide on the population is directly related to its movement. Yet, prediction of future failure potential and hence future risk to population is necessary in order to avoid further catastrophes and involves the analyses of the origin of seismic instability. The seismic landslide potential is mainly determined by the interaction between the regional seismic hazard and local geological conditions. At a local scale, seismic factors interfering with geological conditions can produce site-specific ground motions. The influence of such Site Effects on instability is the principal topic of this paper, which is divided into two parts, A and B. The present Part A is concerned with the correlation of field data with observed instability phenomena. Field data were obtained on mainly three landslide sites in the Northern Tien Shan Mountains in Kyrgyzstan, Central Asia. Geophysical prospecting, earthquake recordings, geological observation, trenching and geotechnical tests were the main investigation tools. The collected information gives an insight in the geological background of the slope failure and allows us to roughly infer failure mechanisms from field evidence. A detailed analysis of the susceptibility of a mechanism to specific geological conditions will be shown in Part B.
\end{abstract}

\section{Introduction}

Seismically triggered landslides are widespread phenomena within tectonically active mountain ranges. Most of these slope failures are reported to be of small size, such as rock

Correspondence to: H.-B. Havenith

(hb.havenith@ulg.ac.be) or soil falls, and only a few of them affect large volumes of soil or rock material (Jibson et al., 1994; Harp and Jibson, 1995). The latter, however, represent the highest risk to both construction and life. A well-known catastrophic landslide is the Huascaran rock-debris avalanche triggered by the $M=7.7$ Peru earthquake in 1970, causing the death of more than 18000 people and burying two villages on its course (Plafker et al., 1971). Further examples are reviewed by Keefer (1984), Hansen and Franks (1991), Faccioli (1995) and Schuster and Highland (2001), such as the cataclysm (100 000 casualties) related to loess-landslides triggered by the $M=8.5$ Haiyuan earthquake (NW China) in 1920, the enormous destruction caused by the huge seismically induced rockslide avalanche on Mount St. Helens almost contemporaneous with the eruption of the volcano in 1980, and the less voluminous but still fatal debris flow-slide triggered by the $M=7.6$ El Salvador earthquake in 2001, burying houses and hundreds of people in Las Collinas.

Though most case-histories of seismic landslides are known for their direct impact on population, some are famous for their high mobility: e.g. the Sherman rock avalanche triggered by the $M=8.5$ Alaska earthquake in 1964 that became notorious by its spectacular spreading of several km over a glacier (Shreve, 1968).

The slope movement characterized by its volume, run out and velocity, represents the imminent cause of the risk and generally attracts most interest. The failure's origin also needs to be analysed in order to predict future landslide potential. Therefore, seismic landslide distributions are correlated with the "predisposing factors" (term after Faccioli, 1995), such as material properties, ground water level, layering, fracturing and slope geometry. The dynamic effect is usually taken into account by correlations with peak ground acceleration (PGA) and/or shaking intensity distributions as well as with the proximity to the activated fault (MMI or Arias intensity). By comparing the shaking effects of a series of events, several surface features constantly reveal wave amplifications related to the local geological conditions. The 
latter are commonly called Site Effects, which are generally associated with enhanced vibration within sediment filled valleys (Borcherdt, 1970; Bard, 1995), but also hills and mountain ridges revealed to amplify ground motion (Bard, 1995; Spudich et al., 1996; Athanasopoulos et al., 1999). Evidence for topographic amplification effects on slope stability were shown by slope failures close to convex crests caused by the El Asnam earthquake in 1980 (Durville and Méneroud, 1982), by earthquake-triggered rock falls preferentially affecting ridge crests (e.g. $M=7.6$ Guatemala earthquake, 1976: Harp et al., 1981) or by coastal bluff failures induced by the Loma Prieta earthquake in 1989 (Griggs and Plant, 1998). Though many examples of such observations exist in literature (see also Hadley, 1964; Schuster et al., 1996; Ochiai et al., 1996), detailed studies of the "cause and effect" are scarce. The local scale interaction between geological and seismic factors is the topic of the present paper and is analysed on the basis of case studies undertaken on landslide sites in the Northern Tien Shan in Kyrgyzstan, Central Asia. On these sites, geophysical prospecting, earthquake recordings, geological observation, trenching and geotechnical tests allowed us to obtain a large set of field data. Rough failure mechanisms could be defined from the field evidence. Further insight in the landslide processes and the discussion of failure susceptibility with regard to specific geological factors is presented in Part B of this paper.

\section{Seismo-tectonics and landslide occurrence in Tien Shan and examples from the Pamir}

The Tien Shan (Fig. 1) is one of the most active parts of the Central Asian neotectonic mountain belt. This system of high ranges (up to $7000 \mathrm{~m}$ a.s.1.) was formed mainly in Pliocene-Quaternary time due to large-scale warping of the Caledonian and Hercinian basement and overlaying Paleogene-Neogene deposits. Its present structure consists of anticline-ridges divided by synclines and graben-depressions corresponding to the intra-mountain basins (Chedia, 1986). Ridges and depressions are often bounded by neotectonic faults that are still active and may be considered as the main structures likely to produce seismic events. The Tien Shan and bordering regions (Kyrgyzstan, Tajikistan, eastern Uzbekistan, south-eastern Kazakhstan and north-western China) are affected by large to catastrophic earthquakes every 5 to 10 years (Aitmatov et al., 1997) and the concomitant seismic hazard is one of the highest on Earth.

\subsection{Landslides in the Tien Shan (with special reference to} Kyrgyzstan) and in the Pamir

Historically, strong earthquakes in the Tien Shan Mountains as well as in the adjacent Pamirs have been accompanied by numerous landslides, sometimes causing most of the observed damage, casualties and loss of property. Landslide case-studies (Fig. 1) shown in this paper are related to the 1885 Belovodsk earthquake (first mentioned by Ig- natiev, 1886), the 1911 Kemin earthquake (Bogdanovich et al., 1914) and the more recent 1992 Suusamyr earthquake (Ghose et al., 1997). Many surface effects are also induced, e.g. by the $M=7.3$ Verny earthquake in 1887 (Mushketov, 1890), the $M=8.3$ Chilik earthquake in 1889 (Mushketov, 1891), the $M=7.4$ Sarez earthquake in 1911 (Preobrazhenski, 1920), the $M=7.4$ Chatkal earthquake in 1946 (Leonov, 1965), the $M=7.6$ Khait earthquake in 1949 (Leonov, 1960) and by the $M=5.5$ Gissar earthquake close to Dushanbe in 1989. The latter event, though of minor magnitude, triggered a debris slide (flow) killing hundreds of people in a village close to the Tajik capital. In 1911, the Sarez earthquake triggered one of the largest historic landslides, the famous Usoi rockslide $\left(2.210^{9} \mathrm{~m}^{3}\right)$ that blocked the Murgab river by the highest natural (and constructed) dam in the world (about 500-600 m high; Gaziev, 1984) and formed the Sarez Lake. The 1949 Khait earthquake in Tajikistan caused numerous landslides and, in particular, a long run out (5$6 \mathrm{~km})$ rock avalanche $\left(250-40010^{6} \mathrm{~m}^{3}\right)$ that buried the Khait town with thousands of inhabitants.

\section{Landslides triggered by the Belovodsk, Kemin and Suusamyr earthquakes}

First documented observations of seismic surface effects in Kyrgyzstan were performed after the $M=6.9$ Belovodsk earthquake (located in Fig. 1) affecting the northern slopes of the Tien Shan (Ignatiev, 1886) as well as the region around the capital Bishkek (that time called Pishpek). According to contemporaneous reports and to oral accounts, the earthquake caused many slope failures. In this regard, it will be discussed in the next section whether two neighbouring rock avalanches (Fig. 2) located close to the village of Bielogorka at an epicentral distance of less than $15 \mathrm{~km}$ are related to this earthquake.

The Kemin $M_{s}=8.2$ earthquake in 1911 was one of the strongest events ever recorded in the Tien Shan (Fig. 1). It was studied in detail soon after it had happened and described in the special monograph of Bogdanovich et al. (1914). Recently, in 1996-2000, its surface effects were reinvestigated by Delvaux et al. (2001). This earthquake caused numerous landslides and rock falls, which occurred all over the seismically affected zone along the activated faults segments (cumulated length of more than $200 \mathrm{~km}$ ). Failed slopes were composed of quaternary deposits as well as of hard rocks generally affected by superficial weathering. In addition to huge rock glaciers and debris flows of several tens of millions of $\mathrm{m}^{3}$ formed at high altitudes (above $2500 \mathrm{~m}$ a.s.l., after Delvaux et al., 2001), the largest landslides were two rockslides, one within the Kemin valley, the other north of the lake Issyk$\mathrm{Kul}$ at some $80 \mathrm{~km}$ east of the presumed epicentre. The first rock avalanche (about $1510^{6} \mathrm{~m}^{3}$ ) made of limestone material occurred along the activated Chon Kemin fault (E-W rupture zone shown in Fig. 1) at about $60 \mathrm{~km} \mathrm{~W}$ of the epicentre, and is known to have buried a village of yourts with 38 inhabitants. The other non-fatal rockslide (Fig. 3) will be described 


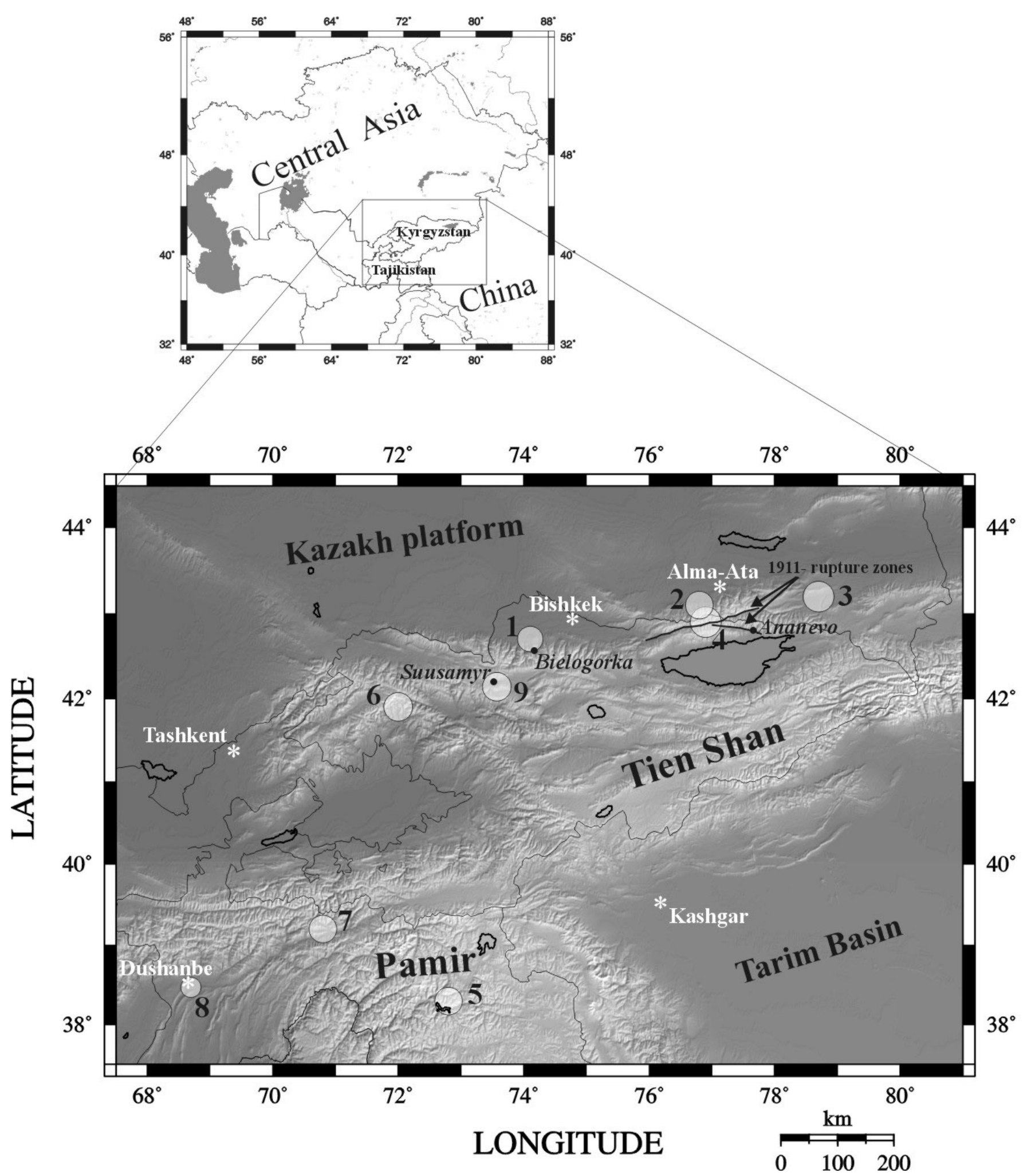

Fig. 1. (a) Location of Kyrgyzstan and Tajikistan. (b) Map showing the morphology of the Tien Shan and Pamir, the rupture zone related to the 1911 Kemin earthquake and location of the investigated sites. Strong earthquakes cited in the text are plotted on the map: (1) $M=6.9$ Belovodsk, 1885; (2) $M=7.3$ Verny, 1887; (3) $M=8.3$ Chilik, 1889; (4) $M=8.2$ Kemin, 1911; (5) $M=7.4$ Sarez (see also Sarez lake), 1911; (6) $M=7.4$ Chatkal, 1946; (7) $M=7.4$ Khait, 1949; (8) $M=5.5$ Gissar, 1989; (9) $M=7.3$ Suusamyr, 1992. 

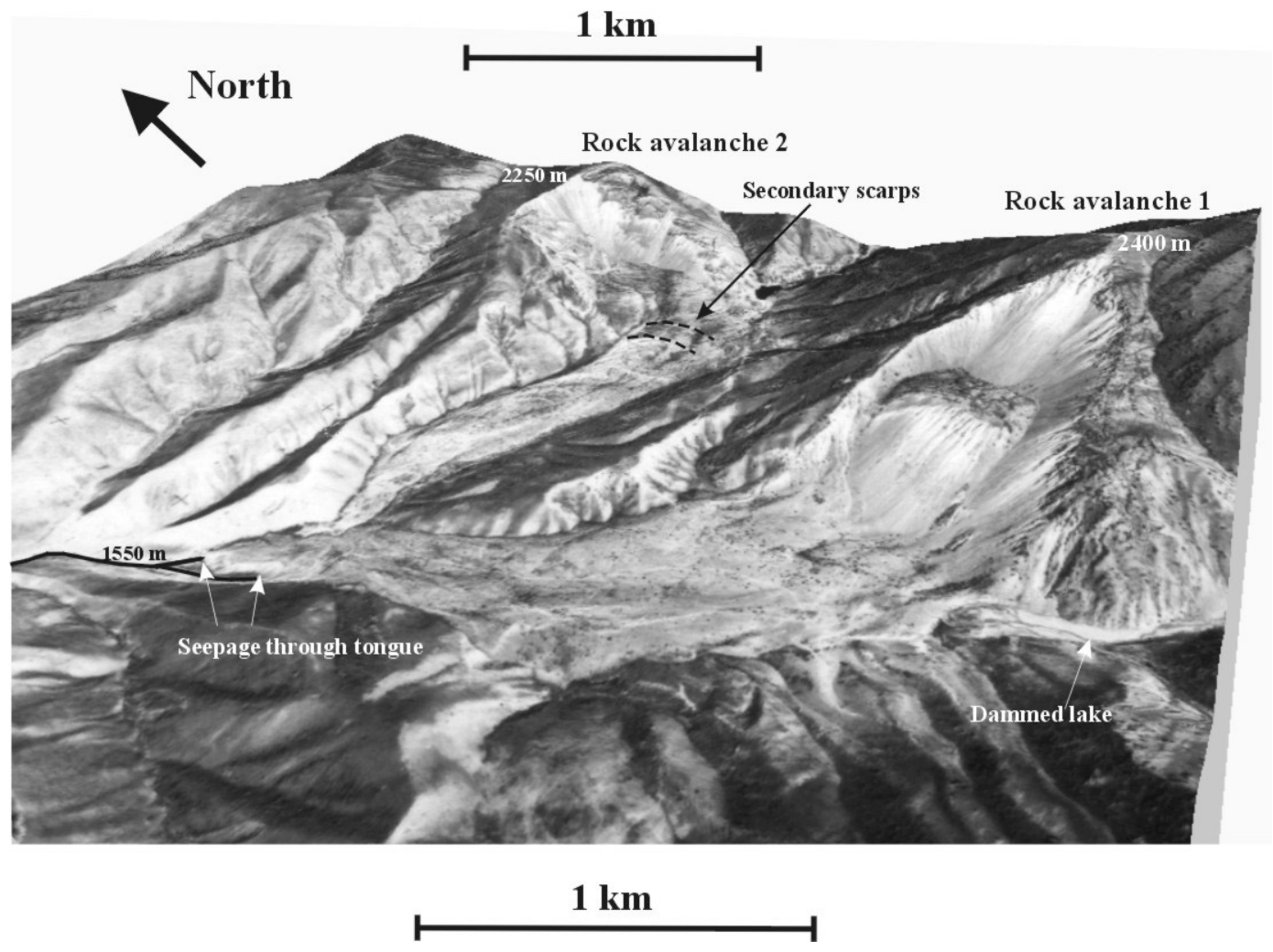

Fig. 2. DEM combined with stereographic view on the 2 rock avalanches of Bielogorka and related geomorphic features.

a)

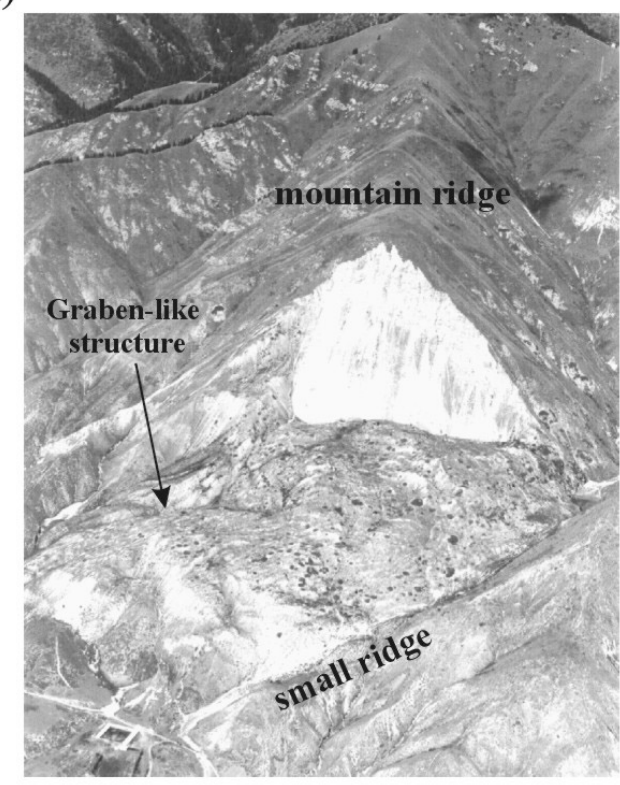

b)

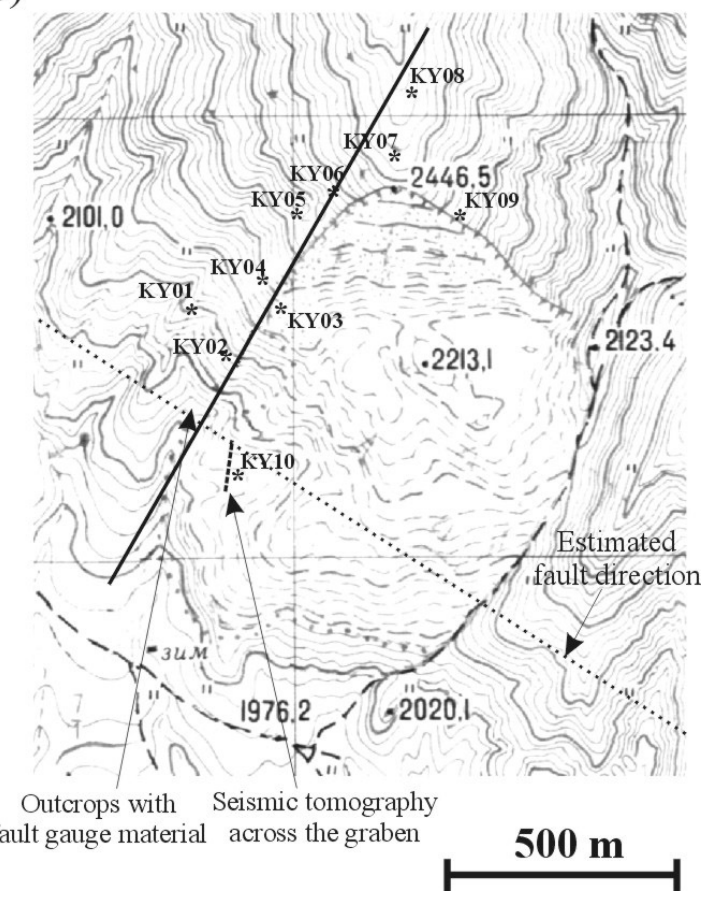

Fig. 3. (a) Helicopter Photograph of the Ananevo rockslide with location of the graben structure and the small ridge (in front) that blocked the rockslide. (b) Map of the landslide with location of seismological stations KY01 to KY10 and location of seismic profiles. The long dashed line corresponds to the estimated fault direction, the thick black line is the NNE-SSW profile along the seismological stations (see Fig. 11). The location of outcrops of fault material is indicated. 
in the following section and is called hereinafter the Ananevo rockslide.

The most recent strong $\left(M_{s}=7.3\right)$ earthquake in the Tien Shan occurred on 19 August 1992 about $100 \mathrm{~km}$ southwest of Bishkek (Fig. 1). It caused widespread surface deformations in the Suusamyr basin and on the southern slopes of the Suusamyr range - in the Toluk and Belaldy river valleys. The largest triggered rockslide affected the headwater slopes of the Belady river (Fig. 1) and later led to formation of a disastrous mudflow killing about 35 people, more than a half of all casualties caused by the event (Ghose, 1997). Several small to medium-sized landslides slid from the southern slope of the Chet-Kurumdy ridge (Fig. 7) composed of the Neogene and Quaternary deposits and located in the lower part of the Suusamyr valley. One of the latter, the Suusamyr debris slide, was studied in detail and will be described in the next section.

\section{Geological analysis of the Bielogorka, Ananevo and Suusamyr landslides}

\subsection{The Bielogorka twin rock avalanches (Fig. 2)}

A 3-D view of the rock avalanches is shown in Fig. 2, based on the construction of a digital elevation model combined with the stereographic view computed from a pair of aerial photographs.

Geological observations were made by Geeninckx (1999) in the field all around the two rock avalanches and on aerial photographs covering a surface of about $300 \mathrm{~km}^{2}$. From outcrops close to the landslides and by analysing the samples from the tongue it could be determined that the failed rocks are principally made of sandstone, locally intruded by andesitic dykes. The scarps cut by the rock avalanches into these rocks are enormous, more than $600 \mathrm{~m}$ high and wide for rock avalanche 1 (RA1) and $400 \mathrm{~m}$ high and wide for rock avalanche 2 (RA2). The summit of the RA1 scarp is located at a rock promontory, while the top of the RA2 scarp almost exactly follows a mountain crest. The entire volume of RA1 can be estimated to more than $2010^{6} \mathrm{~m}^{3}$, while RA2 amounts to about $1010^{6} \mathrm{~m}^{3}$.

Structural data for rock fracturing collected all over the site and within the scarp of RA2 reveal two main orientations of joints. They are also reflected by the principal bearing of lineations observed on aerial photographs: the first set has a strike of about $\mathrm{N} 10^{\circ} \mathrm{E}$, the second of $\mathrm{N} 100-130^{\circ} \mathrm{E}$. The first orientation corresponds also to the sliding direction of RA2 (towards $\mathrm{N} 190^{\circ} \mathrm{E}$ ), while the second fracture orientation is almost parallel to the sliding direction of RA1 (towards $\mathrm{N} 300^{\circ} \mathrm{E}$ ). Joints studied on outcrops principally dip into the slope and do not form any unstable rock-wedges.

Joint spacing and filling were studied in addition to fracture orientation. The influence of the presence of andesitic dykes resulting in closer joint spacing could be observed (approximately two times closer, i.e. less than $\mathrm{dm}^{3}$ ). The induced strong fracturing does, yet, not imply intense weath- ering of the sandstone rocks, neither do the fractures present coating. On the other hand, andesitic rocks are clearly affected by weathering processes.

The two rock avalanches are not only spectacular slope failures due to their large volume but also due to the geometry of the displaced material. A remarkable feature of RA1 is the block of several millions of $\mathrm{m}^{3}$ remaining inside the landslide scarp. Secondly, the tongues of both rock avalanches testify to the high mobility of the material during its downslope motion. Particular features visible at the surface are pressure ridges perpendicular to the sliding axis and high lateral crests bordering the channel-like depression along the main axis. In both cases, the avalanches hit the opposite valley slopes and rose up to more than $100 \mathrm{~m}$ before falling back into the valley. The trajectory of RA 2 made a bend of almost $90^{\circ}$ and the propagation of the movement downhill was accompanied by the formation of secondary scarps separating the lower tongue from the upper shelf-like accumulation of rock material (Fig. 2). The components of the tongue are principally small blocks of pebble-size and only a smaller fraction consists in fine-grained material or larger blocks. The small content of crushed material (e.g. rock powder) that constitutes the tongues are quite permeable, as proved by strong seepage at the toes of the two tongues. The principal origin of the oozing water are lakes formed by upstream damming of small brooks. From the surface morphology of the tongues, it can be seen that these natural dams have never been overtopped by flowing water; seepage seems, therefore, to be the only active mechanism of water-flow.

The global sub-surface geometry of the tongue of RA1 was studied by four $250 \mathrm{~m}$ and four $120 \mathrm{~m}$ long seismic refraction profiles (24 geophones) using, respectively, explosives and sledgehammer as source Geeninckx (1999). The results indicate that the thickness of the displaced material decreases from $60 \mathrm{~m}$ in the central part close to the scarp to $30 \mathrm{~m}$ at the toe. Though the site has been precisely investigated, it is still not proved that the two rock avalanches were really triggered by the Belovodsk earthquake. Even the dating of trees on the tongues did not allow us to elucidate this uncertainty. The trees are, in fact, too young (less than 50 years), and seem to have grown long after the development of the avalanche tongues. Thus, the principal argument favouring a seismic origin for the rock avalanches is their clustering, such as it could be proved by Hermanns et al. (2002) in the case of ancient rock avalanches in the Argentine Andes. Further, the occurrence of the rock avalanches in the vicinity (at about $15 \mathrm{~km}$ ) of the Belovodsk earthquake, the strongest one that has ever occurred in historical times in this region, corroborates the link with this event. Therefore, we conclude that a connection with this event is likely but not certain.

\subsection{The structure of the Ananevo rockslide (Fig. 3)}

The Ananevo rockslide located at about $7 \mathrm{~km} \mathrm{NNW}$ of the Ananevo village is one of the most prominent features produced by the Kemin earthquake. This rockslide was studied intensively for two months by a geophysical-seismological 
survey (Havenith et al., 2002) including also structural and geotechnical analyses as well as trenching inside the frontal material. The geology of the site is characterized by lightcoloured granitic rocks that make up the bright appearance of the triangular scarp (Fig. 3a), which can be seen in good weather from the southern Issyk-Kul lake border, at a distance of more than $80 \mathrm{~km}$. The scarp is $250 \mathrm{~m}$ high and more than $500 \mathrm{~m}$ wide at its base.

Failure took place at the southern end of a mountain ridge just above the discontinuous fault activated by the 1911 Kemin earthquake. According to Delvaux et al. (2001) this section of the Chon Aksu fault is a thrust gently dipping towards the northeast into the collapsed slope. Evidence of the presence of the fault is the related scarp with a height of $1 \mathrm{~m}$ at $3 \mathrm{~km}$ WNW of the site increasing up to almost $10 \mathrm{~m}$ at $12 \mathrm{~km}$ to the WNW. On the site itself, outcrops at the foot of the southwest slope (located in Fig. 3b) show particularly disintegrated and weathered granitic rocks over a distance of about $100 \mathrm{~m}$. These probably belong to the central part of a broader fault zone, with an estimated total thickness of more than $600 \mathrm{~m}$. At about $100 \mathrm{~m}$ to the SE of these outcrops, a graben-like depression marks the foot of the southwest slope (Fig. 3a). According to Bogdanovich's description in 1914 "... the collapse of the tremendous landslide led to formation of the secondary ruptures in front of the slide body" (translated from Bogdanovich et al., 1914, p. 73). Actually, this feature may also be associated with the reverse fault rupture mechanism generating extensional structures on the hanging wall, such as shown by Philip and Meghraoui (1980) with the example from the El Asnam earthquake in 1980. In order to determine the internal structure, a $140 \mathrm{~m}$ long seismic tomography profile has been performed across the graben (see location in Fig. 3b). The profile includes 36 geophones with a $4 \mathrm{~m}$ spacing and shots with a sledge-hammer at every geophone. The recorded first arrival times were processed with the SARDIN software (Demanet, 2000). As result, a seismic tomography section showing the distribution of sub-surface P-velocities has been obtained (Fig. 4). From this, the inferred underground geometry seems to reflect the surficial structure of the graben depression bordered by opposite fracture systems accommodating the normal displacements.

Further structural data were collected all around the Ananevo rockslide site. About 250 measurements of fracture orientation were made on outcrops inside the landslide scarp and along the neighbouring valleys. Out of the large dispersion of fracture orientations three main families can be distinguished from the equal area contour plot of respective poles projected on the lower hemisphere (Fig. 5). The three families are represented by the three corresponding mean great circles: $\mathrm{N} 66^{\circ} \mathrm{E} 48^{\circ} \mathrm{SE}, \mathrm{N} 142^{\circ} \mathrm{E} 69^{\circ} \mathrm{SW}, \mathrm{N} 300^{\circ} \mathrm{E} 35^{\circ} \mathrm{NE}$. The latter fracture set has an orientation similar to that of the underlying fault and may thus be related to its neotectonic activity. The origin of the two first sets is not clearly established and may be connected with either neotectonic activity or with pluton emplacement. Irrespective of their origin, these two sets seem to provide the first elements of possible instability, they form a dihedron with basal planes dipping southward, i.e. out of the slope, but with a higher $\operatorname{dip}\left(45-50^{\circ}\right)$ than the estimated slope angle before failure $\left(\sim 30-35^{\circ}\right)$. Their role in the initiation of the failure will be discussed later. The final step of the landslide process has been analysed on the basis of features observed within the tongue materials. The landslide body is quite compact and covers an area of about $0.5 \mathrm{~km}^{2}, 800 \mathrm{~m}$ long and up to $600 \mathrm{~m}$ wide. Its volume is estimated to be about $1510^{6} \mathrm{~m}^{3}$. During its motion, the material hit against a small ridge (see location in Fig. 3a) and turned slightly to the right before it abruptly stopped. This can be concluded from the particularly steep $80 \mathrm{~m}$ high frontal slope at the toe. Remarkable is also the thickness of the tongue of $100 \mathrm{~m}$ in its central part as determined by two $300 \mathrm{~m}$ long seismic refraction profiles (24 geophones over $115 \mathrm{~m}$, with a $185 \mathrm{~m}$ offset) using explosives as source. The tongue material is principally made of granitic arenites or dm-size disintegrated granitic boulders partly weathered into arenites and clay. Below the scar and in the central part of the tongue, house-size blocks made of apparently coherent granite lie on the surface of the displaced material (and maybe also inside). East of the scarp a small lake is dammed by the rockslide, but due to the compaction and the large fraction of fine material, seepage through the tongue is limited and outflow at the toe is weak.

All around the toe, the granitic material overlies a loamy mass that forms a 7 to $10 \mathrm{~m}$ high shelf (Fig. 6a). In order to get information on the stopping mechanisms of the tongue three trenches have been excavated at the southwest end of the toe - first (C) at the foot of the above mentioned loamy shelf (Fig. 6d), the second (B) at its top (Fig. 6c) and the third (A) about $10 \mathrm{~m}$ higher within the main toe material (Fig. 6b). Features exposed in trenches B and C demonstrate that granite debris pushed loose deposits that rested on the slope foot, like a bulldozer, in front of them. Thus, they piled up an almost $10 \mathrm{~m}$ thick belt below the toe of the landslide body. We expect that pushing of loose material in front of the moving debris and its accumulation contributed to the limited run out of the landslide. The other factor that prevented the transformation of the rockslide into a long-run out rock avalanche, typical for slides of such volume, was probably the collision with the small ridge southeast of the tongue (Fig. 3).

Internal movement mechanisms, at least in the frontal part were revealed by the observation made in trench A: the presence of large fragments of buried soil and subsoil loamy sand resting on the displaced crushed granites and overlaid (overthrusted) by the same material indicates internal thrusting even above the basal sliding surface of the landslide. The global geometry of the frontal part can, thus, be described as a duplex-like structure.

\subsection{The Suusamyr debris slide (Fig. 7)}

The Suusamyr debris slide belongs to a series of surface effect induced by the $M=7.3$ Suusamyr earthquake within the Suusamyr valley. Most of these effects are located along the southern slopes of the E-W trending Chet-Korumdy ridge (Fig. 7b). The ridge is made of up-folded Neogene clayey- 


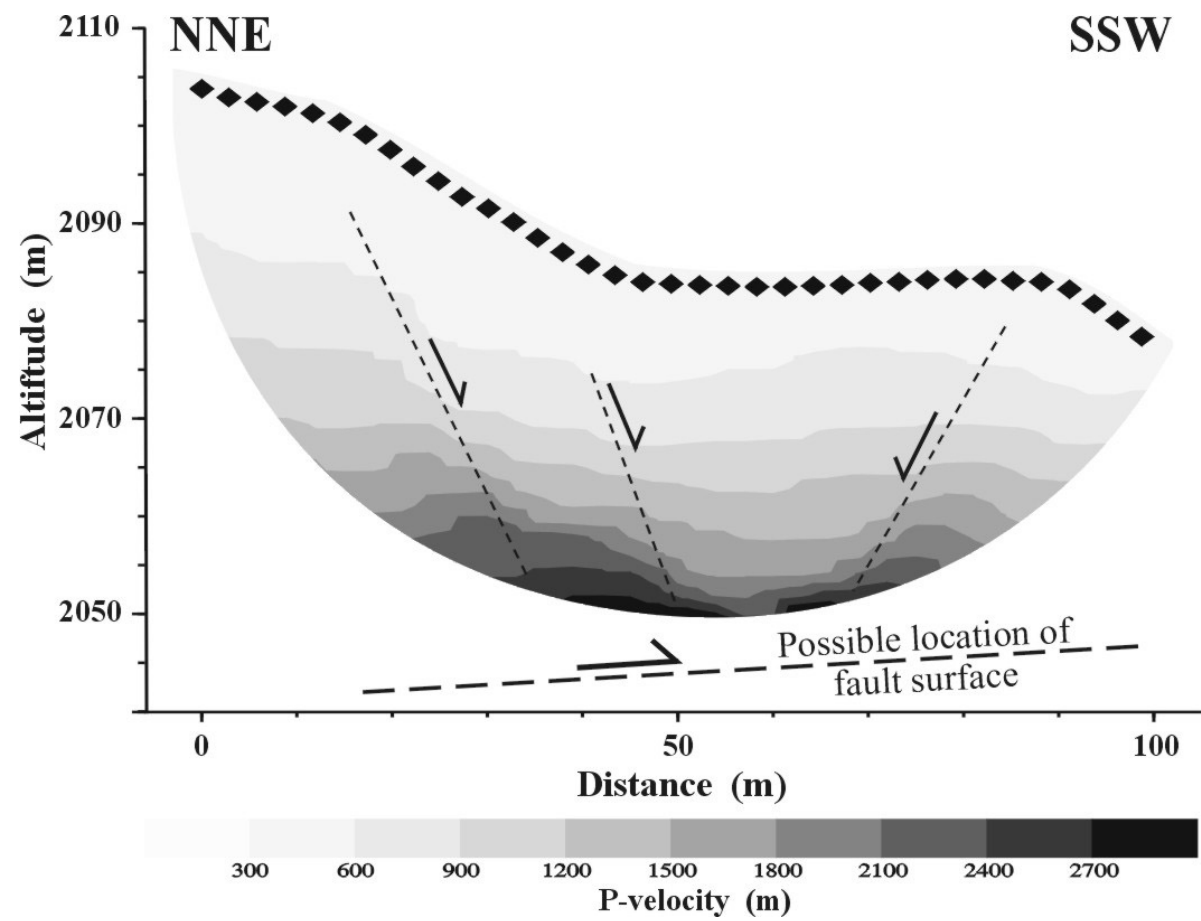

Fig. 4. Seismic tomography (36 geophones with $5 \mathrm{~m}$ spacing) across the graben above the gently north-eastward dipping hanging wall of the Chon Aksu fault (estimated location of the fault surface is indicated). Extensional features inferred from the seismic tomography are marked by thin dashed lines.

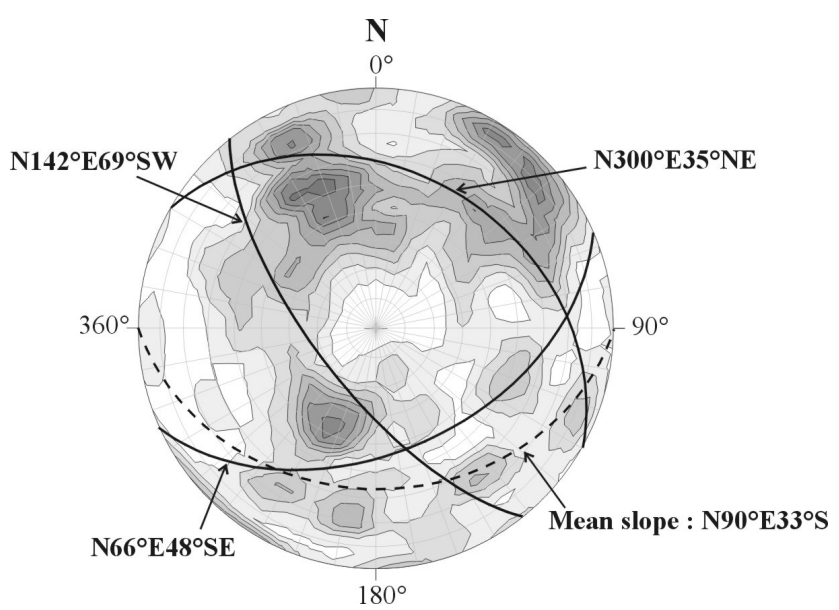

Fig. 5. Density contour plot (equal area, lower hemisphere) of poles of 250 measured fracture planes with great circles corresponding to the three regions marked by highest pole concentration. Indicated is also an estimated mean slope angle prior to failure.

sandy sediments overlain by a $0-60 \mathrm{~m}$ thick Quaternary arenite layer.

At the crest of the ridge, a gravitational graben, $10 \mathrm{~m}$ wide and extending over more than $100 \mathrm{~m}$ along the crest, formed during the earthquake between a main south-facing and secondary north-facing scarps (see approximate location in Fig. 7a). North of the crest, no significant surface effects have been detected. The formation of the graben seems to be directly related to the shaking of the ridge because no signs of failure were visible before the earthquake. From the comparison between aerial photographs before and after the $\mathrm{Su}-$ usamyr earthquake in 1992, it could, however, be inferred that most of the present landslides were caused by reactivation of former failures. A good example is shown by the pair of before-and-after aerial photographs of the Suusamyr debris slide (Figs. 8a and b). On the photograph prior to 1992, a fracture is clearly visible at the location of the present $50 \mathrm{~m}$ high headscarp (pointer 1 in Fig. 8) and denudation occurred already where afterwards the secondary scarp had developed (pointer 2 in Fig. 8).

These two scarps, the headscarp and the lower secondary scarp are the upper and lower bounds of a multi-rotational debris slump. Laterally, the slump is bordered by a small scarp in the east, the continuation of the headscarp, and by a seepage zone in the west (Fig. 8c). Observations made in a trench (Trench 2 in Fig. 8c) excavated in the vicinity of this zone and data from electrical tomographic profiles indicate that seepage mainly occurs due to the presence of impermeable clays at small depth below the more permeable arenites. Below the secondary scarp the debris material spread further downhill and turned into a debris flow (Fig. 8c) covering the Bishkek-Osh highway (see location in Fig. 7) under a few metres of wet arenites. The cause of the transformation of the slump into a flow is probably related to changed hydrogeological conditions during sliding. In fact, it is likely that the landslide body gained in permeability by moving downhill with increased ground water flow within fractures and 


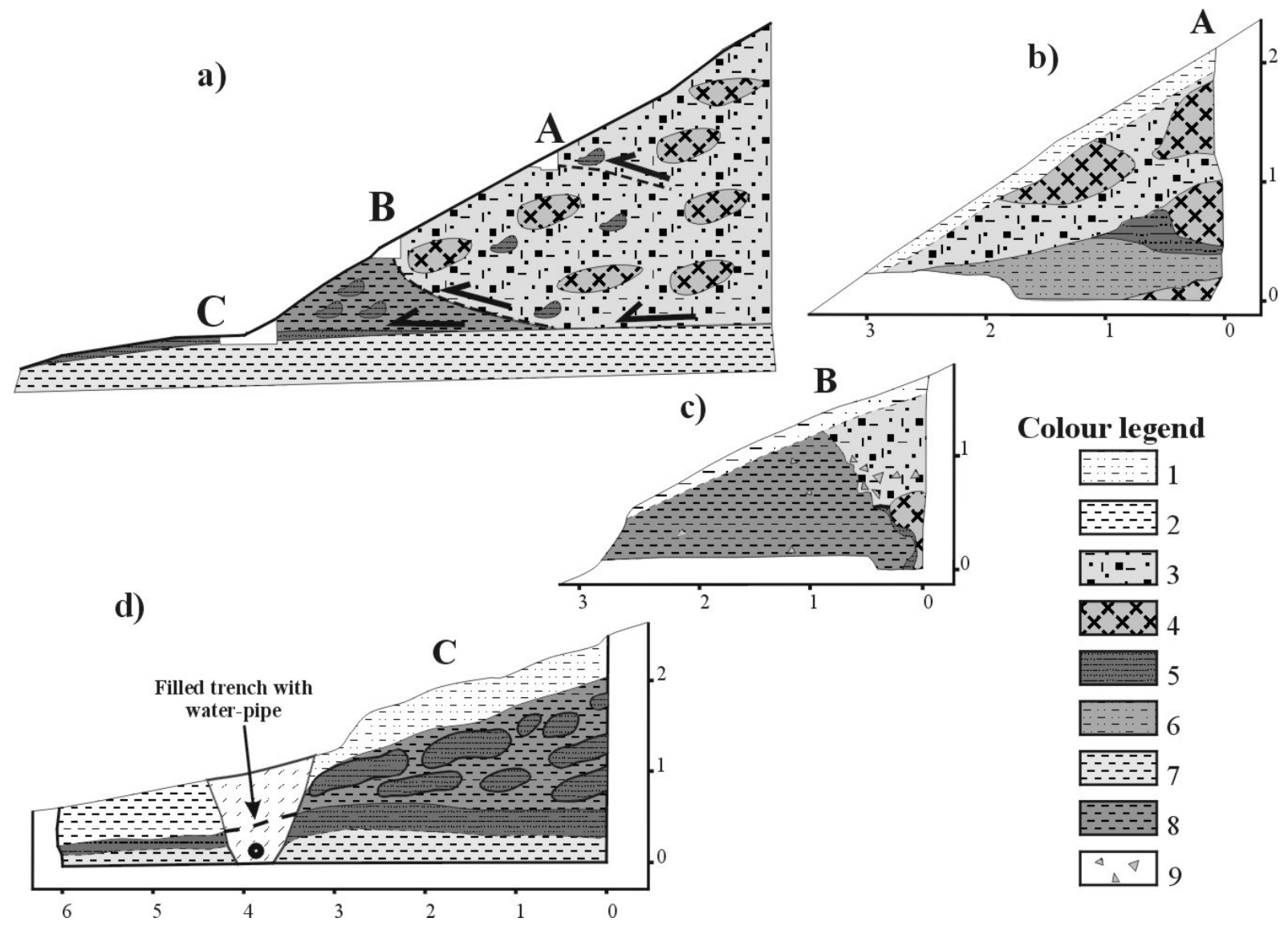

Fig. 6. Frontal tongue structure. (a) Schematic view of the toe materials with location of the three trenches A, B, C shown in (b), (c) and (d), respectively. Materials: (1) deluvium, (2) white compact loam, (3) crushed grey granite - arenites, (4) blocks and boulders of pink granite, (5) buried soil, (6) brown subsoil loamy sand, (7) white subsoil loam (in situ), (8) light brown loam, (9) small granite fragments. Axis-scales are in metres.

looser material. Seepage still occurs at the base of the secondary scarp. At present, the cover over the debris flow has been removed and a new highway is being built. Further excavation of the landslide material to the sides of the highway has been performed in order to provide additional stability.

\section{Geophysical 3-D models of the Ananevo and Su- usamyr sites}

Whereas only a few geophysical data have been obtained on the Bielogorka rock avalanche 1, detailed geophysical prospecting has been performed on the Ananevo and the Suusamyr sites. In the following only a review of the results will be made. Detailed descriptions of the surveys can be found in Havenith et al. (2000) for the Suusamyr site and Havenith et al. (2002) for the Ananevo site.

On both sites, seismic refraction data have been recorded, but on the Suusamyr landslide additional electrical profiles have been obtained as this technique is well adapted to soft soil sediments. Seismic data were either analysed by classical seismic refraction processing (Burger, 1992), by surface wave inversion (Herrmann, 1987) or as seismic tomography
(Demanet, 2000). Electrical data were exclusively processed in terms of electrical tomography. Besides defining the geometry of the landslide body, the main goal on both sites consisted in determining the superficial velocity and/or resistivity distribution of the in situ geological materials. The calibration of the geophysical data with observations on outcrops and in trenches as well as with geotechnical tests on samples allowed us to link geophysical parameters with geological materials. All geophysical results have then been combined in order to establish 3-D geological models of the sites.

\subsection{The 3-D Ananevo model}

The 3-D model of the Ananevo site is essentially based on seismic data and thus represents the 3-D P- and S-velocity distribution over the site (Fig. 9a). The decreasing S-velocity $(V s)$ from $3470 \mathrm{~m} / \mathrm{s}$ within the bedrock towards $400 \mathrm{~m} / \mathrm{s}$ at the surface, such as shown by the model (see also Table 1), can be directly related to the increasing effect of weathering on the rock material. Further, the seismic data revealed that rocks at the mountain crest are more deeply weathered than along the slopes. 


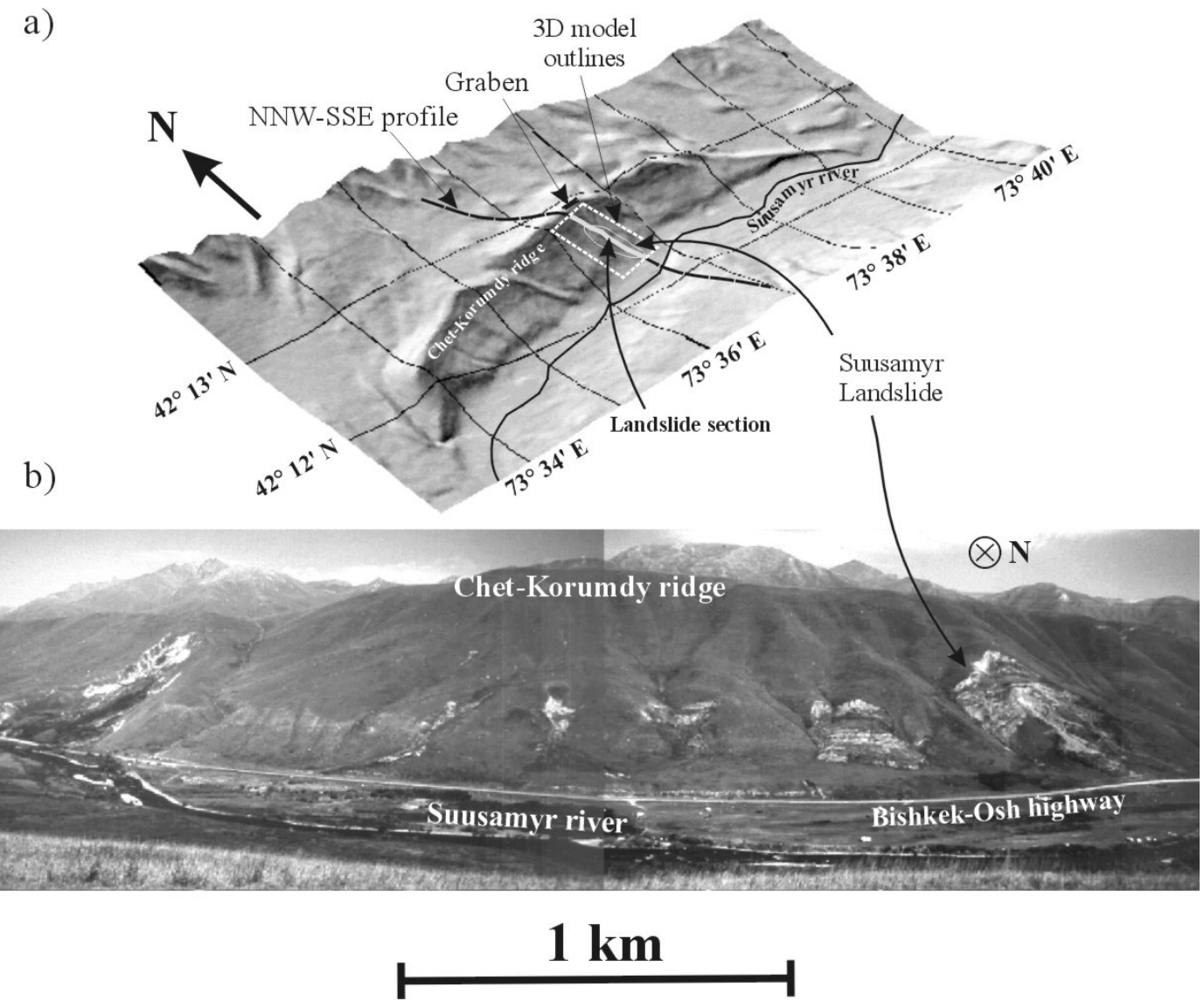

Fig. 7. (a) Digital elevation model of the Chet-Korumdy ridge prior to 1992, with location of the graben, the Suusamyr landslide, the outline of the 3-D geological model and the Landslide section in Fig. 10. (b) Surface effects including the Suusamyr debris slide triggered by the $M_{S}=7.3$ Suusamyr earthquake in 1992 on the south-facing slope of the Chet-Korumdy ridge. See also location of the Bishkek-Osh highway and the approximate scale.

Table 1. Ananevo: seismic material properties determined from geophysical prospecting

\begin{tabular}{ccc}
\hline Layer $^{\circ}$ & $V p(\mathrm{~m} / \mathrm{s})$ & $V s(\mathrm{~m} / \mathrm{s})$ \\
\hline 1 & 800 & 400 \\
2 & 1700 & 910 \\
3, fault & 3950 & 2180 \\
Bedrock & 6000 & 3470 \\
\hline
\end{tabular}

In addition to the low-velocity layers, the fault zone has been included into the model. Due to the lack of information, the thickness of the fault zone has been estimated at $650 \mathrm{~m}$ and the properties of the fault gauge material (marked by dashed lines in Figs. 9a and b) were chosen as identical to those of the deepest low-velocity layer.

Based on the same features, an additional 3-D model prior to failure (Fig. 9b) has been built by extrapolation of present contour levels and by using seismic information on the depth of the tongue. In Fig. 9b, the estimated location of the sliding plane has been outlined and shows that mainly the two upper weathered rock layers of a maximum thickness of about $80 \mathrm{~m}$
Table 2. Suusamyr: geophysical material properties determined from geophysical prospecting

\begin{tabular}{cccc}
\hline Layer $\mathrm{n}^{\circ}$ & $V p(\mathrm{~m} / \mathrm{s})$ & $V s(\mathrm{~m} / \mathrm{s})$ & Resistivity $(\Omega \mathrm{m})$ \\
\hline 1 & 800 & 300 & $>70$ \\
2 & 2000 & 750 & $<70$ \\
Bedrock & 3200 & 1350 & - \\
\hline
\end{tabular}

were affected by the rockslide.

\subsection{The 3-D Suusamyr model}

In Fig. 10, the present-day 3-D geological model of the Suusamyr site is shown. This model includes a superficial arenite layer of medium to high resistivity and low Pvelocity ( $>70 \mathrm{Ohmm},<1500 \mathrm{~m} / \mathrm{s}$ ), an intermediate silty clay layer (resistivities $<70 \mathrm{Ohmm}$, P-velocity between 1800 and $2100 \mathrm{~m} / \mathrm{s}$ ) and the underlying Neogene sediments. The latter unit was not investigated by the geoelectric profiles due to the limited penetration depth, but could be detected by the seismic profiles and characterized by a P-velocity of more than 
a)

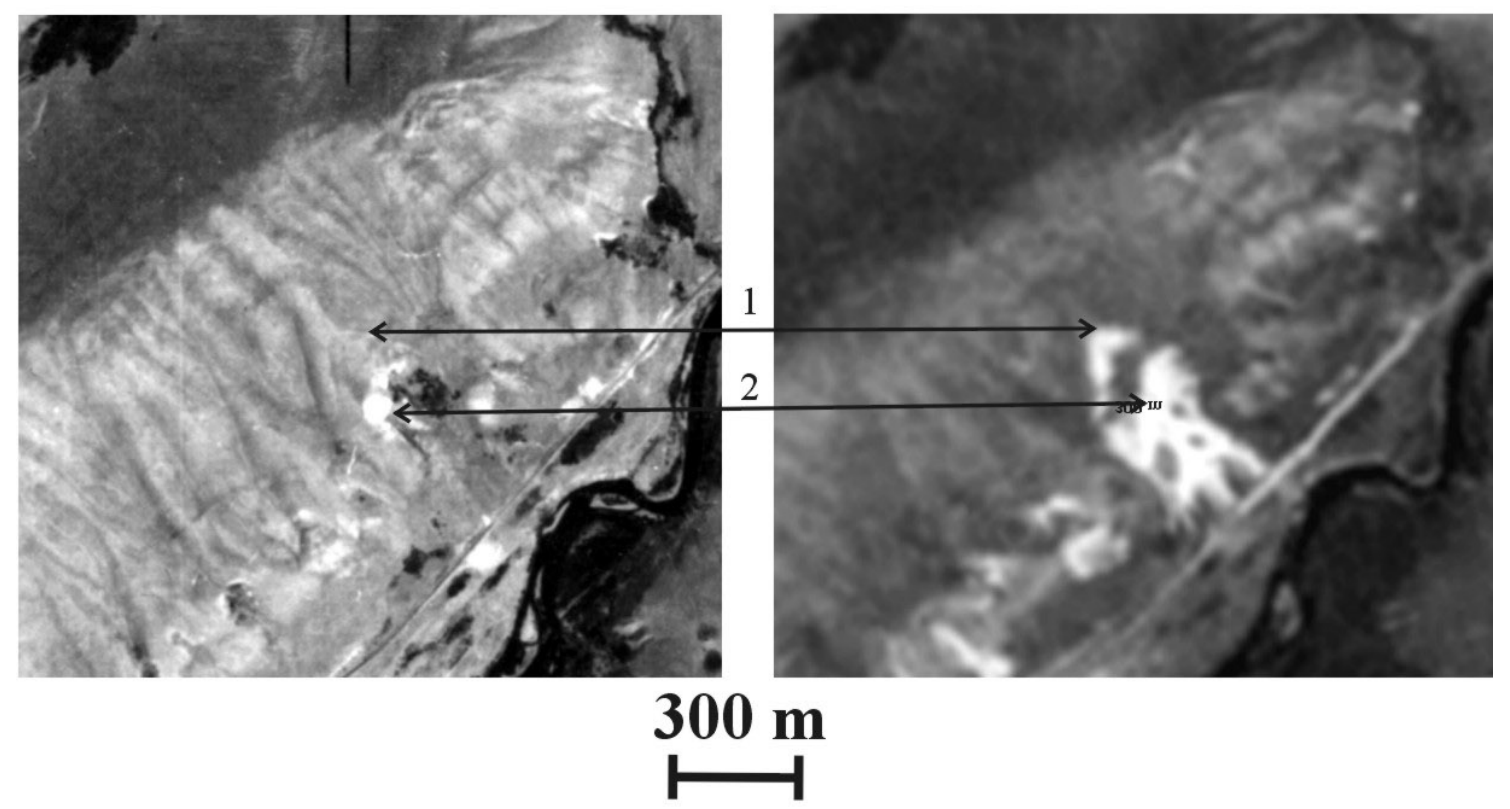

c)

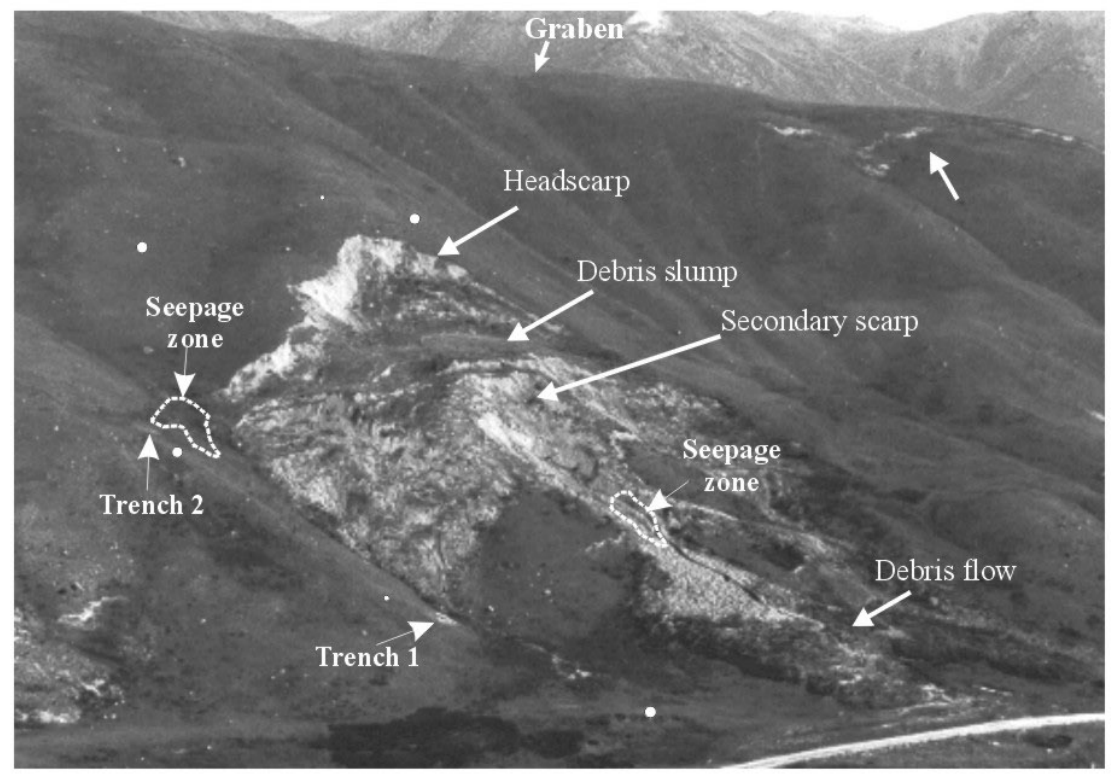

\section{$300 \mathrm{~m}$}

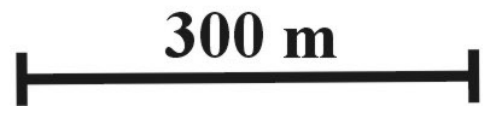

Fig. 8. Aerial photographs (with approximate scale) of the Suusamyr site before (a) and after (b) the 1992 Suusamyr earthquake. Arrow 1 points to the location of the fracture before development of the landslide headscarp. Arrow 2 points to denuded zone before formation of secondary scarp. (c) Photograph of the Suusamyr landslide (with approximate scale) and related geomorphic features. The approximate location of the graben is indicated. 
a)

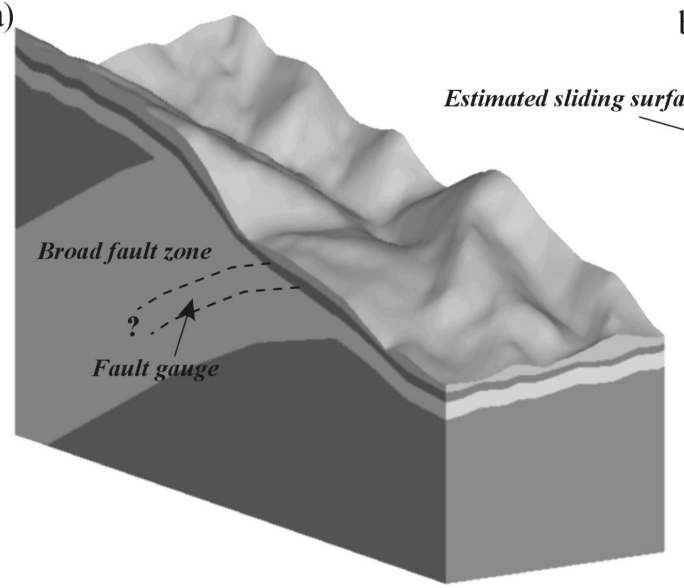

b)

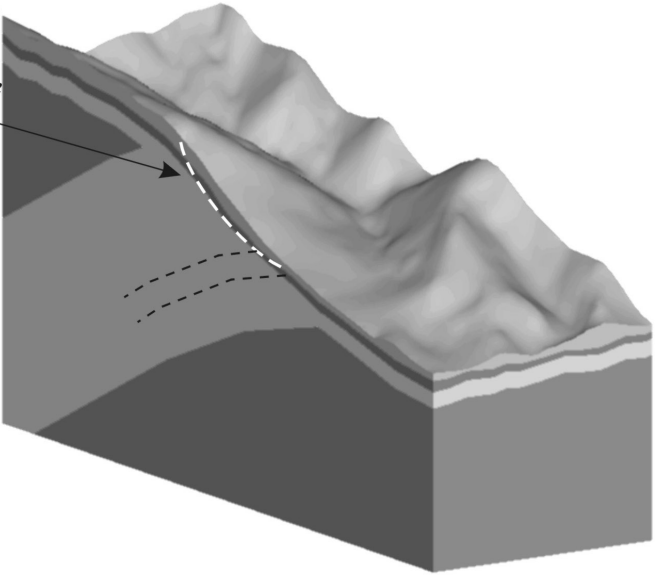

c)

d)

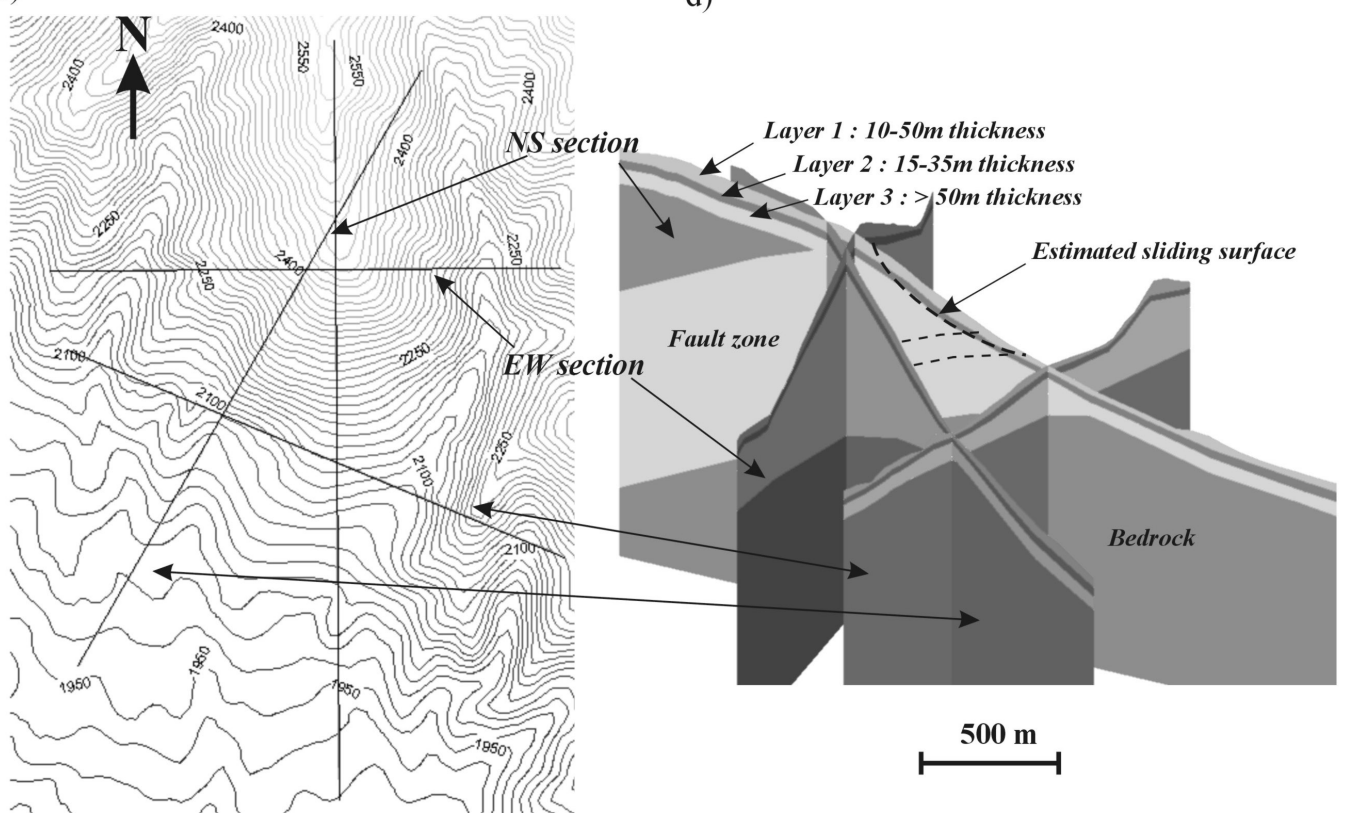

Fig. 9. (a) Eastern part of present-day 3-D geological model with location of the broad fault zone and the inner fault gauge. (b) Eastern part of reconstructed geological model previous to failure with location of the estimated sliding surface. (c) Topographical map (prior to failure) showing location of cross-sections and outline of the headscarp. (d) Sections across the geophysical model previous to failure. Location of layers 1, 2 and 3 and fault zone as well as the estimated sliding surface along cross-section 3 are indicated. 


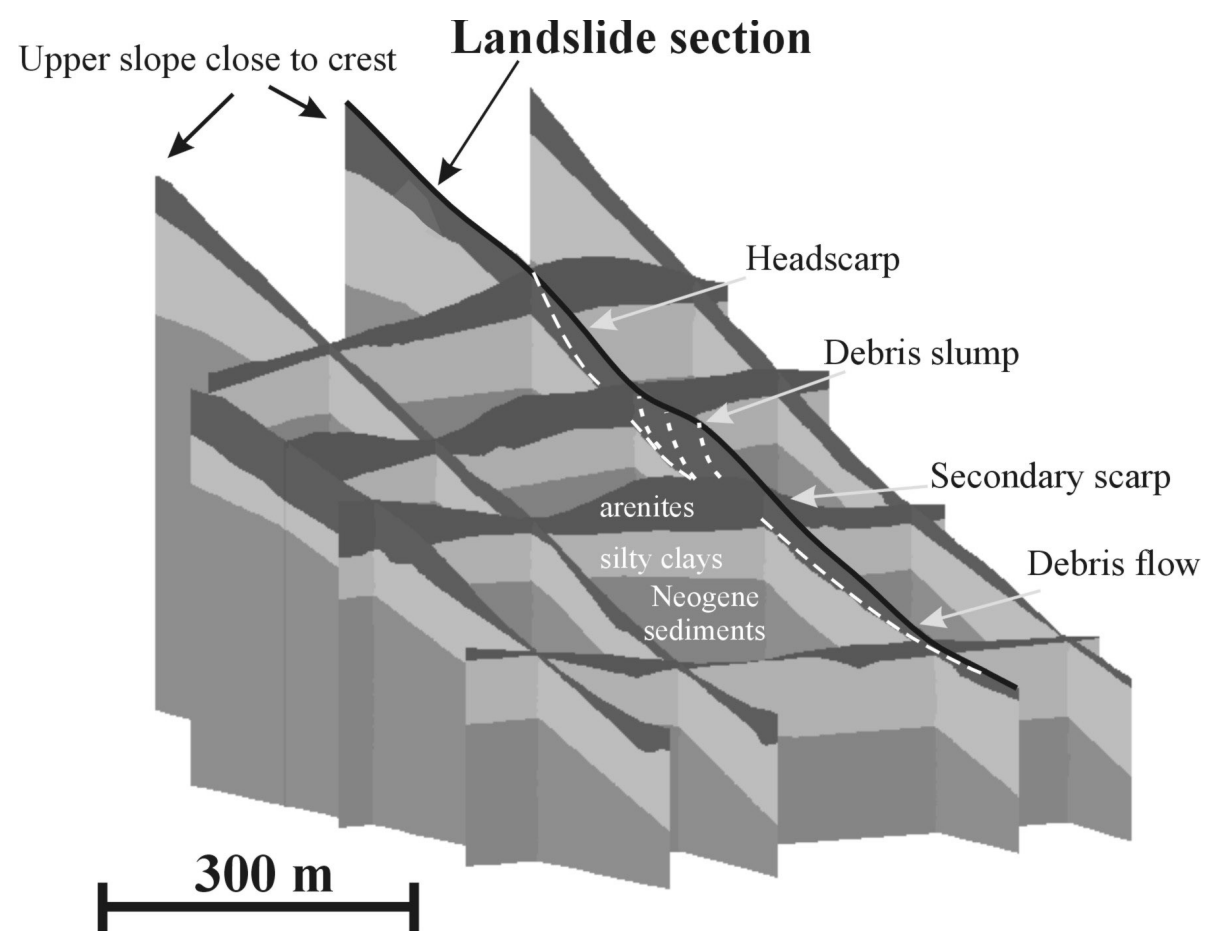

Fig. 10. 3-D model showing the subsurface geology (2 layers and bedrock) of the Suusamyr landslide site. Locations of the headscarp, slump, secondary scarp, flow and estimated locations of sliding surfaces are indicated along the Landslide section.

$3100 \mathrm{~m} / \mathrm{s}$ (see Table 2). From the 3-D geometry it can be seen that the thickness of the surficial arenite layer strongly varies over the site. Besides local accumulation zones of arenites at the foot of the slope, those at higher altitudes are marked by a convex surface morphology. The largest thickness of the arenite layer of more than $50 \mathrm{~m}$ appears close to the crest, such as shown by the section along the landslide axis ("Landslide section" in Fig. 10). Several features of the Suusamyr landslide are indicated along this section: the headscarp, the multi-rotational slump with a maximum thickness of about $40 \mathrm{~m}$, the secondary scarp and the lower part of the landslide, the debris flow and the estimated location of the sliding plane.

\section{Ground motion dynamics}

Seismological field data for earthquake ground motions were collected during two months on the Ananevo site. More than 100 small local and regional as well as large teleseismic events have been recorded by 10 temporary seismological stations around the Ananevo rockslide (see location in Fig. 3b) and one permanent station located at $2.5 \mathrm{~km}$ to the SE. By comparing the recordings of the 10 temporary stations with those from the permanent Reference station in the vicinity of Ananevo village, a clear amplification effect around the rockslide could be revealed. This observation was confirmed by the computation of Standard Spectral Ratios (SSR), i.e. ratios between the smoothed Fourier spectra of time-windows over seismograms recorded by the tem- porary stations and by the Reference station, respectively. These ratios define the Site Effects on the investigated site with regard to the Reference site. All 10 stations around the rockslide revealed spectral amplification of a factor larger than 2. According to the location of the seismological station and within confined frequency ranges, amplification may exceed a factor of 5. Figure 11 shows the distribution of mean Standard Spectral Ratios on the N-S component (parallel to the mountain ridge) along the southwest mountain slope. The computed site effects ( $\mathrm{N}-\mathrm{S}$ component) present a strong variation along the slope comparable with the variation of the surface morphology and the investigated underground geology. Strongest amplification of values higher than 8 between 0.7 and $2 \mathrm{~Hz}$ exclusively affects the stations close to the mountain crest. These amplified frequencies increase from the top towards the foot of the slope in connection with the decreasing thickness of the surficial lowvelocity layer. This dependency on the geological structure has been confirmed by 2-D and 3-D elasto-dynamic finite element-modelling (Havenith et al., 2002).

\section{Influence of geological factors on instability}

The geological factors investigated within the different casestudies can be subdivided into fractures/joints, subsurface layering (soil) - weathering (rock), surface morphology, and ground water level. During the earthquake, the seismic input interacted with these factors and led to the dynamic slope failure. 

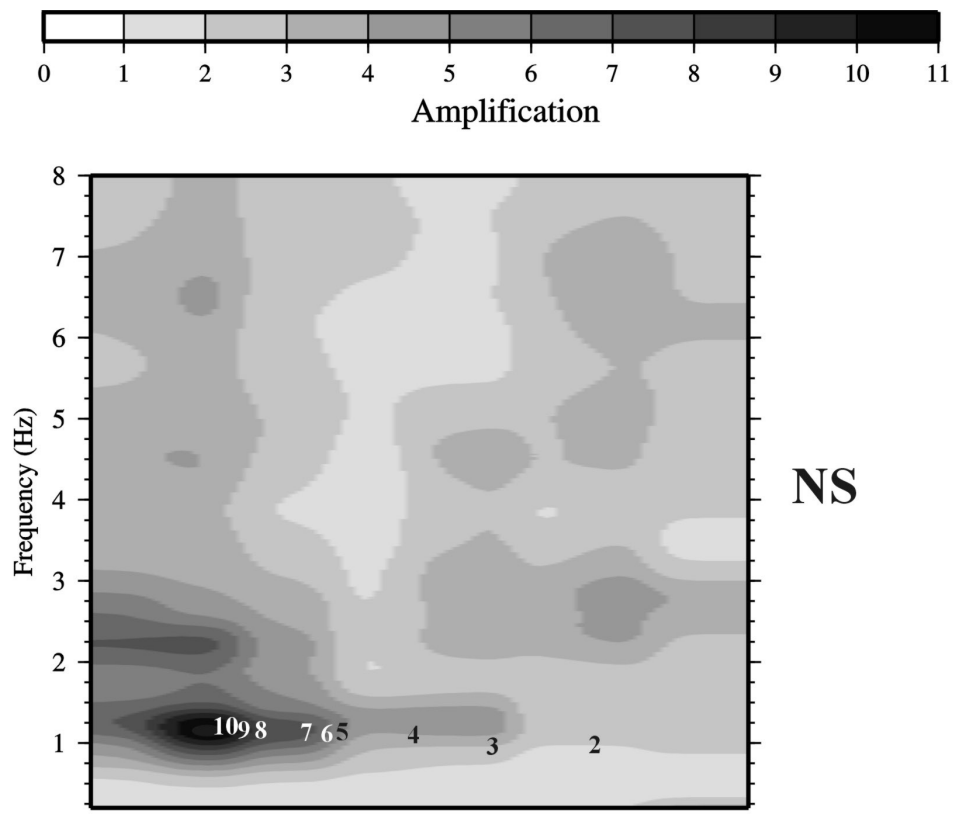

NS

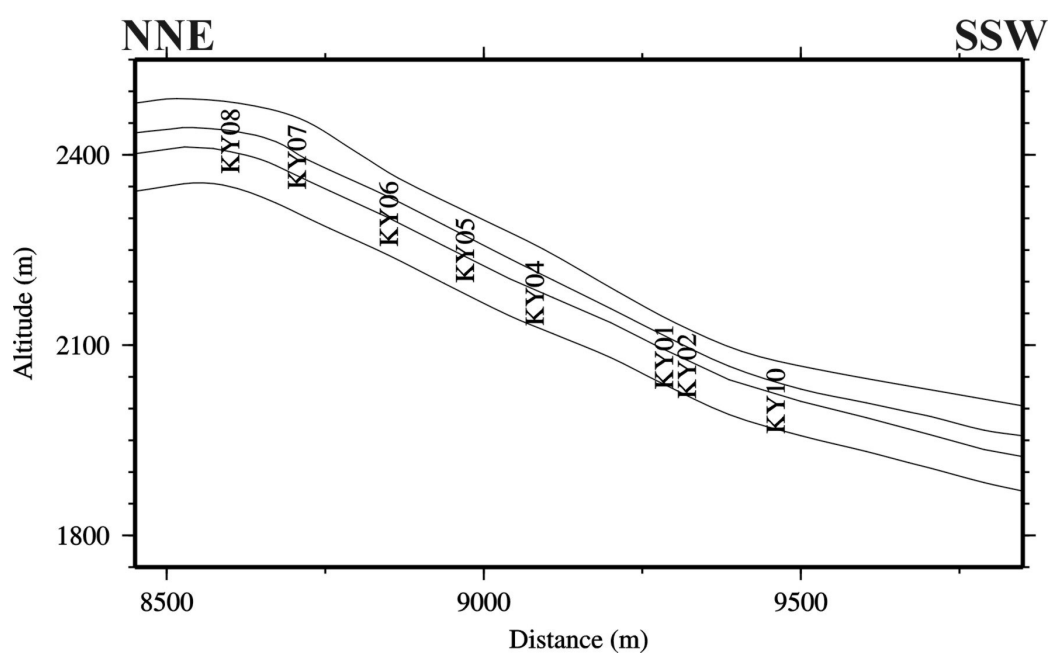

Fig. 11. Distribution of NS-component SSR along the south-western slope of the landslide mountain (see location of profile on map in Fig. 3b).

\subsection{Seismic rock-slope failures}

Rock-slope failures were investigated at the Bielogorka and the Ananevo sites. For such type of surface effects the rock structure is generally considered as the principal stabilityfactor. In both cases, the Bielogorka rock avalanches and the Ananevo rockslide, intersecting joints form stable rockwedges with basal planes either steeply dipping into the slope (Bielogorka) or dipping out of the slope, but with a higher angle (Ananevo). Thus, instability was not induced by a simple rock-wedge failure, and other mechanisms need to be involved. A mechanism suggested for this type of rock fabric is the tensile bending-failure observed from many active landslides. Most of them are long-term slope instabilities that developed under quasi-static conditions, such as the melting of glaciers and/or the undercutting of the slopes by rivers: e.g. La Clapière and Séchillienne landslides in the French Alps described by Vengeon et al. (1999). The toppling of rock columns or blocks induced by the increased slope angle finally results in tensile failure at a depth where the bending overcomes internal rock strength. The coalescence of the tensile failure surfaces at the base of toppling rock columns generates the basal failure surface. Two problems arise from the application of this general concept of the mechanism. In fact, the general mechanism concerns 2-D structures or 2.5D (3-D rock columns along an infinite plane slope), while the geometries met at the different sites are typically 3-D: rock promontory (Bielogorka RA1), end of mountain ridge (Ananevo) and slope headed by a ridge crest (Bielogorka RA2). Particularly for the Bielogorka RA1 and the Ananevo rockslides, the convex surface morphology needs to be con- 
sidered since it allows rock-wedges formed by intersecting joints to move laterally. Thus, pure bending may interact with lateral slip and define a much more complex mechanism, such as tensile bending-slip failure.

Further, since this mechanism is known from its longterm action on slopes, the question still remains open if it is also effective within such a short time-span as an earthquake event. Yet, it would be difficult to study in the field such a process that may be called dynamic tensile bending-slip failure, which lasts a couple of seconds or minutes, at most. Therefore, numerical simulations were performed with a distinct element code and are presented in Part B of this paper.

\subsection{Seismic soil-slope failures}

Soils principally differ from rocks by their much larger deformability and by a more continuous (not homogeneous) structure. These characteristics need to be taken into account for the analysis of failure mechanisms. Considering the layered structure of the Suusamyr site, the triggering of the debris slide is likely to be due to a bedding failure. Evidence for this is given by observations in trenches and related geotechnical tests. Inside the lower trench (Trench 1 in Fig. 8c), slip surfaces were observed within a wet transition zone between arenites and silty clays, hinting to instability phenomena within this zone. Shear tests on samples from the trench showed that the friction angle $\left(22^{\circ}\right)$ is actually the lowest at the contact between the arenite and silty clay layer. Arenites are characterized by a significantly higher friction angle $\left(30^{\circ}\right)$ while the silty clays have a slightly higher friction angle $\left(24^{\circ}\right)$. Thus, it is most likely that the arenite slid over the silty clays along a failure surface confined to the contact between the two materials.

The presence of a pre-existing fracture and the related deformation at the present location of the head-scarp probably supported instability by a local reduction of the shear strength within the arenite layer. Reduction of the shear strength at the basal sliding surface was probably enhanced by the presence of ground water above the bedding contact. The presence of ground water was actually observed in both trenches $\mathrm{W}$ of the landslide and was clearly shown by the geoelectric profiles in terms of low-resistivity zones.

\section{Conclusions}

Three landslide sites have been investigated in the Northern Tien Shan mountains in Kyrgyzstan, Central Asia. In all three cases, evidence exists for a seismic triggering of the slope failures: the twin rock avalanches at Bielogorka were probably triggered by the $M=6.9$ Belovodsk earthquake, the rockslide at Ananevo was triggered by the $M=8.2$ Kemin earthquake and the Suusamyr landslide was induced by the $M=7.3$ Suusamyr earthquake through reactivation of an initial instability. Prospecting of the site geology was performed by geophysical methods, fracture analyses and geotechnical tests as well as a seismological survey (on the
Ananevo site, only). 3-D digital elevation models have been built for all sites and combined with the construction of the 3D underground geology for the Suusamyr and Ananevo sites, only. For the latter, a 3-D model prior to failure has also been reconstructed. For the two rock slope sites at Bielogorka and Ananevo, a tensile bending-(slip) failure has been suggested as probable trigger mechanism. The process is supported by the rock fabric and the surface topography, which enable the surficial weathered and hence deformable rocks to bend under the effect of the seismic ground motion and to break by tensile failure. The Suusamyr debris slide affected loose deposits of the "soil-category". The sliding of the arenite mass is thought to have occurred by bedding failure. Evidence for the presumed type of deformation is shown by slip surfaces and low measured friction angles within the transition zone observed in an excavated trench. Further predisposing factors for instability are the pre-event fracture at the location of the headscarp and the presence of ground water above the basal failure surface.

The definition of these failure mechanisms was partly determined by a consideration of landslide occurrences in quasi-static circumstances. It may, therefore, be questioned if these generally long-term mechanisms may be effective within a short time-span under dynamic conditions. "Preliminary numerical answers" are given in Part B with examples of landslide simulations using a distinct element code. Particular attention will be paid to the impact of surface topography and layering and of related amplification effects on the instability processes.

Acknowledgements. The research leading to this article was funded by the European Community (EC, DG XII contract IC15-CT970202) and by the Fonds National de la Recherche Scientifique of Belgium. We wish to thank the KIS and GEOPRIBOR teams, students and scientists, who helped in acquiring the geophysical data. We are also indebted to $\mathrm{S}$. Geeninckx, LGIH, Liège, who provided additional information on the Bielogorka site.

\section{References}

Aitmatov, I. T., Torgoev, I. A., and Alioshin, Y. G.: Monitoring of dangerous geodynamical areas, in Proc. of the 30th Int. Geol. Congr., Beijing, China, 4-14 August, Vol. II and III, 1-7, 1997.

Athanasopoulos, G. A., Pelekis, P. C., and Leonidou, E. A.: Effects of surface topography on seismic ground response in the Egion (Greece) 15 June 1995 earthquake, Soil Dyn. Earthqu. Eng., 18, 135-149, 1999.

Bard, P.-Y.: Effects of surface geology on ground motion: recent results and remaining issues, in Proc. of the 10th European Conference on Earthquake Engineering, Vienna, 305-323, 1995.

Bogdanovich, M. M. C., Kark, J., Korolkov, B., and Muchketov, D.: Earthquake of the 4th January 1911 in the northern districts of the Tien Shan, Tr. Geol. Com. Ser., 89, (in Russian), 1914.

Borcherdt, R. D.: Effects of local geology on ground motion near San Francisco Bay, Bull. Seis. Soc. Am., 60, 29-61, 1970.

Burger, H. R.: Exploration Geophysics of the shallow subsurface, Prentice Hall, (Ed) Marshak, K. G., 1-489, 1992.

Chedia, O. K.: Morphostructures and the newest tectogenesis of the Tien Shan, Ilim Publishing House, Frunze, 1986. 
Delvaux D., Abdrakhmatov, K. E., and Strom, A. L.: Landslides and surface breaks of the $1911 M_{S} 8.2$ Kemin earthquake, Kyrgyzstan, Russian Geology and Geophysics (Geologiya i Geophysika), 42, 1167-1177, 2001.

Demanet, D.: Tomographies 2-D et 3-D à partir de mesures géophysiques en surface et en forage, $\mathrm{Ph}$. D. Thesis, Liege University, Belgium, 2000.

Durville, J.-L. and Méneroud, J.-P.: Phénomnes géomorphologiques induits par le séisme d'El Asnam, Algérie. Comparaison avec le séisme de Campanie, Italie. Bull. liaison. Labo. P. et Ch., 120, 13-23, 1982.

Faccioli, E.: Induced Hazards: Earthquake triggered Landslides, in Proc. of the 5th Int. Conf. on Seismic Zonation, 1908-1931, 1995.

Gaziev, E.: Study of the Usoi landslide in Pamir, in Proc. of the 4th Int. Symp. on Landslides, Toronto, Vol. 1, 511-514, 1984.

Geeninckx, S.: Etude par télédétection, levé de terrain et prospection géophysique de glissements déclenchés par tremblement de terre (Kyrgyzstan), Mémoire à l'Université de Liège, Faculté des sciences, Liège, Belgium,1-48, 1999.

Ghose, S., Mellors, R. J., Korjenkov, A. M., Hamburger, M. W., Pavlis, T. L., Pavlis, G. L., Mamyrov, E., and Muraliev, A. R.: The $M_{s}=7.31992$ Suusamyr, Kyrgyzstan earthquake: 2 . Aftershock Focal Mechanisms and Surface Deformation, Bull. Seis. Soc. Am., 87, 23-38, 1997.

Griggs, G. B. and Plant, N.: Coastal-bluff failures in northern Monterey Bay induced by the earthquake, in: The Loma Prieta, California, earthquake of 17 October 1989 - Landslides, (Ed) Keefer, D., USGS Prof. Paper 1551-C, C33-C50, 1998.

Hadley, J. B.: Landslides and related phenomena accompanying the Hebgen Lake earthquake of 17 August 1959, Geol. Surv. Prof. Paper, 453, 107-138, 1964.

Hansen, A. and Franks, C. A. M.: Characterisation and mapping of earthquake triggered landslides for seismic zonation, Proc. of the 4th Int. Conf. on Seismic Zonation, 149-194, 1991.

Harp, E. L., Wilson, R. C., and Wieczorec, G. F.: Landslides from the 4 February 1976, Guatemala earthquake, The Guatemala earthquake of 4 February 1976, Geol. Surv. Prof. Paper 1204-A, 1-35, 1981.

Harp, E. L. and Jibson, R. C.: Landslides triggered by the 1994 Northridge, California, earthquake, Bull. Seis. Soc. Am., 86, S319-S332, 1995.

Havenith, H. B., Jongmans, D., Abdrakhmatov, K., Trefois, P., Delvaux, D., and Torgoev, I. A.: Geophysical investigation of seismically induced surface effects: case study of a landslide in the Suusamyr valley, Kyrgyzstan, Surv. in Geoph., 21, 349-369, 2000.

Havenith, H.-B., Jongmans, D., Faccioli, E., Abdrakhmatov, K., Bard, P.-Y.: Site effects analysis around the seismically induced Ananevo rockslide, Kyrgyzstan, Bull. Seis. Soc. Am., 92 (8), 120, 2002.

Hermanns, R. L., Niedermann, S., Ivy-Ochs, S., Kubik, P. W., and Strecker, M. R.: Paleoseismic triggering of multiple paleoland- slides in the NW - Argentine Andes, in: Geophysical Research Abstracts, 27th General Assembly of the EGS, Nice, 4, EGS02A-00134, 2002.

Herrmann, R.: Computer programs in Seismology, Sint Louis University, 1987.

Ignatiev, I. V.: Earthquake in the Tokmak district in 1885, in Proc. of the Imperial Russian Geographic Society, 22, Issue 2, 150-164, (in Russian), 1886.

Jibson, R. W., Prentice, C. S., Borissoff, A., Rogozhin, E., and Langer, C. J.: Some observations of landslides triggered by the 29 April 1991 Racha earthquake, Republic of Georgia, Bull. Seis. Soc. Am., 84, 963-973, 1994.

Keefer, D. K.: Rock avalanches caused by earthquakes: source characteristics, Science, 223, 1288-1290, 1984.

Leonov, N. N.: The Khait, 1949 earthquake and geological conditions of its origin, Proceedings of Academy of Sciences of the USSR, Geophys, Series 3, 409-424, (in Russian), 1960.

Leonov, N. N.: Role of geological structure in the formation of residual deformations of soils during earthquakes, in: Seismic Microzoning, Transactions of Institute of Physics of the Earth RAS, 36(203), 132-136 (in Russian), 1965.

Mushketov, I. V.: The Verny earthquake of 28 May (9 June) 1887, in Proc. of Geological Committee 10, St. Petersburg, 1890.

Mushketov, I. V.: The Chilik earthquake, in: The materials for study of earthquakes in Russia, Issue 1, St. Petersburg, 11-42, (in Russian), 1891.

Ochiai, H., Kitahara, H., Sammori, T., and Abe, K.: Landslides triggered by the 1995 Hyogo-Ken Nanbu earthquake in the Rokko, in: Proc. Landslides, (Ed) Senneset, 1007-1012, 1996.

Philip H. and Meghraoui M.: Structural analysis and interpretation of the surface deformations of the El Asnam earthquake of 10 October Tectonics, 1983, 17-49, 1980.

Plafker, G., Ericksen, G. E., and Concha, J. F.: Geological aspects of the 31 May 1970, Peru earthquake, Bull. Seis. Soc. Am., 61, 543-578, 1971.

Preobrazhenski, I. A.: The Usoi blockage, (in Russian), 1920.

Schuster, R. L., Nieto, A. S., O'Rourke, T. D., and Crespo, E.: Mass wasting triggered by the 5 March 1987 Ecuador earthquakes, Eng. Geol., 42, 1-23, 1996.

Schuster, R. L. and Highland, L. M.: Socioeconomic and environmental impacts of landslides in the western hemisphere, USGS Open-File Report, 01-276, 2001.

Shreve, R. L.: Sherman landslide, Alaska, Science, 154, 1639 1643, 1966.

Spudich, P., Hellweg, M., and Lee, W. H. K.: Directional topographic site response at Tarzana observed in aftershocks of the Northridge, California, earthquake: implications for mainshock motions, Bull. Seis. Soc. Am., 86, S193-S208, 1996.

Vengeon, J.-M., Giraud, A., Antoine, P., and Rochet, L.: Contribution à l'analyse de la déformation et de la rupture des grands versants rocheux en terrain cristallophyllien, Can. Geotech. J., 36, 1123-1136, 1999. 